Research Article

\title{
Comparative Environmental Evaluation of Straw Resources by LCA in China
}

\author{
Xiaoyu Shang $\mathbb{D},{ }^{1,2}$ Siqi Song $\mathbb{D},{ }^{1}$ and Jingwei Yang $\mathbb{D}^{1}$ \\ ${ }^{1}$ School of Civil Engineering and Architecture, Northeast Electric Power University, Jilin 132012, China \\ ${ }^{2}$ The Bartlett, Faculty of the Built Environment, University College of London, London WC1E 6BT, UK \\ Correspondence should be addressed to Xiaoyu Shang; shangxiaoyu@neepu.edu.cn
}

Received 1 November 2019; Revised 21 January 2020; Accepted 28 January 2020; Published 24 February 2020

Academic Editor: Teresa M. Piqué

Copyright ( $\odot 2020$ Xiaoyu Shang et al. This is an open access article distributed under the Creative Commons Attribution License, which permits unrestricted use, distribution, and reproduction in any medium, provided the original work is properly cited.

Crop straw, as a widely used biomass resource, can be processed to produce renewable energy and green products. However, about $70 \%$ of straw were burned in the open air, causing serious environmental pollution and air pollution. In order to reduce the burden on the environment, the different straw management strategies are comparatively studied and evaluated by applying the life-cycle assessment (LCA) method. Within the system boundary from cradle to grave, three alternative scenarios, including straw particleboard, straw cement-bonded particleboard, and straw direct combustion power generation, are compared with the current common treatment (straw open burning). The comprehensive inventory analysis on each treatment scenario is carried out indepth, and the corresponding resource consumption and environmental impact of each treatment scenario are calculated, respectively. The LCA results showed that the environmental impacts of reusing crop straw to produce straw particleboard and cement-bonded particleboard (Scenario 1 and Scenario 2) is significantly reduced by $6 \%$ and $10 \%$, by comparison with the use of wood resource. Greenhouse gas emissions from straw direct combustion power generation (Scenario 3) processes are reduced by $30 \%$ compared with coal power generation. From the environmental point of view, the scenario of straw particleboard product has the smallest impact on the environment, while straw open burning is not an advisable way due to the highest environmental impact from the highest greenhouse gas emissions and acidification effects. From the perspective of energy consumption, the energy consumption for the combustion power generation is the smallest in all scenarios. It is suggested that governments are supposed to construct reasonable scenarios for the straw disposition based on the local development status and condition. The research results can provide scientific guidance for the management strategy of the comprehensive utilization of straw resources.

\section{Introduction}

About 1 billion tons of crop straw was generated each year in China and brought a severe burden to cities and natural environment. Recycling and reusing crop straw is a practice pathway to dispose the agricultural waste. Comprehensive utilization of straw resources can not only improve agricultural efficiency but also save resources and protect the ecological environment $[1,2]$. It is reported that recycled crop straw can be used to produce particleboard, cementitious composite board, and other building materials [3-5], and beyond that, crop straw can also be used for energy conversion for direct-fired power generation [6-8]. These reuse schemes can make full use of excess straw resources and alleviate environmental pressure. Several studies have shown that it is technically feasible to utilize the straw for fiberboard production $[9,10]$. Crop straw can replace wood materials to produce fiberboard with different densities (low, medium, and high densities), which has good mechanical properties and saves forest resources [11]. The cement composite board prepared by using straw as the reinforcing material has low cost, acceptable strength, and good waterproofing performance [12-14]. Furthermore, the characteristics that less sulfur and ash content than coal make inflammable crop straw to be a good fuel resource. Some biomass power generation has been developed by replacing fossil fuels with straw or other agriculture wastes [15-17]. In the case of various possibilities of reuse, it is of significance to adopt scientific and reasonable methods to develop and manage the straw. 
Life-cycle assessment (LCA) is a tool for green products to assess the environmental impact throughout their life cycle that can effectively recognize and quantify the resource consumption and environmental impact of products [18-20]. Several LCA studies on biomass conversion have been published, such as direct biomass combustion for power generation in China, France, and the US [21-24]. Besides, the use of LCA has been mainly applied on energy conversion strategies, such as power generation, biogas, and agriculture. LCA can help compare potential factors and environmental impact types in different stages. Mediumdensity fiberboard was assessed based on LCA during the production process $[25,26]$. Umberto software and Ecoinvent life-cycle inventory database were used to establish different life-cycle models of fiberboard manufacturing [27-29]. Some applications of LCA in power generation were carried out as a life-cycle assessment of straw power generation in Spain. It is found that greenhouse gas emissions in power station reduced and met the EU's $60 \%$ sustainability standard when natural gas is replaced by straw [17]. Moreover, it has saved $1.7 \mathrm{~kg} \mathrm{CO} \mathrm{CO}_{2} \mathrm{eq} / \mathrm{kWh}$ of greenhouse gas emissions when compared with the traditional power generation method [30]. In the application of LCA, multiple schemes and even multifield comparisons can be performed. Not only can it be combined with other methods, such as Technology for Order Preference by Similarity to an Ideal Solution, TOPSIS, for multiobjective decision-making but also sensitivity analysis can be conducted to explore the impact of certain factors on the environment [1, 31]. LCA is conducted for environmental problems of different straw utilization systems, such as direct combustion power generation, biomass conversion to ethanol or biogas, and thermochemical conversion to biodiesel and fertilizer as soil [32]. It is possible to establish a life-cycle assessment model of medium-density fiberboard, bioethanol, combined heat power, and corrugated base paper to compare pollutant emissions from different options and direct incineration [33]. In agriculture, the reuse of straw brings great environmental benefits and avoids the environmental impact of incineration [34, 35]. The life-cycle assessment of the boards and power generation made from waste wood is compared with the traditional landfill treatment. The waste of abandoned materials such as wood can be effectively avoided [36-38].

Overall, scholars have carried out some aspects of LCA research on the reuse of straw, but single resource reuse in these methods or systematical evaluation in the frame of a single form of treatment were always dealt with. There is a lack of multiway comparative study on multiaspect utilization of straw resources, and most of the existing results are only for the impact of the greenhouse effect on the environment, but resource consumption also needs consideration. In this study, a comparative environmental evaluation of straw resources was conducted by LCA based on the data from China. The objectives of the study are to (i) select four typical treatment schemes, including straw particleboard production, straw cement-bonded particleboard production, straw direct combustion power generation, and straw open burning (common management method in China), (ii) evaluate and compare the environmental impacts and energy consumption of the four scenarios, and also (iii) compare these disposal scenarios with the traditional disposal methods of raw materials or fuels. It provides a theoretical basis for improving the environmental quality issues caused by improper straw treatment and promoting the sustainable development of straw resource utilization.

\section{Methodology}

2.1. Study Method. For the sake of providing a reasonable scientific basis for straw management, this study adopted a common method of environmental impact assessment, namely, life-cycle assessment (LCA). According to ISO, LCA research includes four main steps: (1) the determination of research objectives and scope, including system boundaries, functional units, and the determination of evaluation objectives; (2) life-cycle inventory (LCI) analysis and, according to determination of objectives and scope, processing data such as material and energy consumption in all stages of life cycle; (3) impact evaluation and quantitative evaluation of the impact of the inventory; (4) explanation of the results and providing the results for interpretation and analysis. The LCA technical framework is shown in Figure 1.

Since life-cycle assessment studies inevitably require the collection and processing of data sets for different production processes, the results of the evaluation may be affected by different kinds of factors and conditions. In the life-cycle assessment of products, various factors have different effects on the results. At this time, it is necessary to conduct sensitivity analysis. In the evaluation process, other external conditions, such as data collection, data sources, and material transportation distance, have affected the outcome. Therefore, a sensitivity analysis of the greenhouse gas emissions of the studied management systems is conducted to assess uncertainties associated with transport distances, power consumption, and so on. Oracle Crystal Ball is a Monte Carlo simulation software, also known as Monte Carlo Crystal Ball software [39]. The main functions of the software are predictive modeling, prediction, simulation and optimization, random simulation, and uncertainty risk analysis, which can insight into the key factors affecting risk. In Section 3.5, by using the Oracle Crystal Ball software, the key parameters are simulated for 1 million times in the range of $\pm 20 \%$, and the contribution rate of the key parameters to the environmental performance of different scenarios systems was obtained.

\subsection{Objectives and Scope of the Study. Different straw} management scenarios are selected, and the environmental impacts of assessment and comparison scenarios are taken as the research objectives. Three typical resource utilization scenarios are selected and compared with the reference scenario (open burning), and the functional unit of comparison between scenarios is 1 ton of straw. Agricultural production activities such as crop cultivation, farming, and fertilization are not considered in this analysis. 


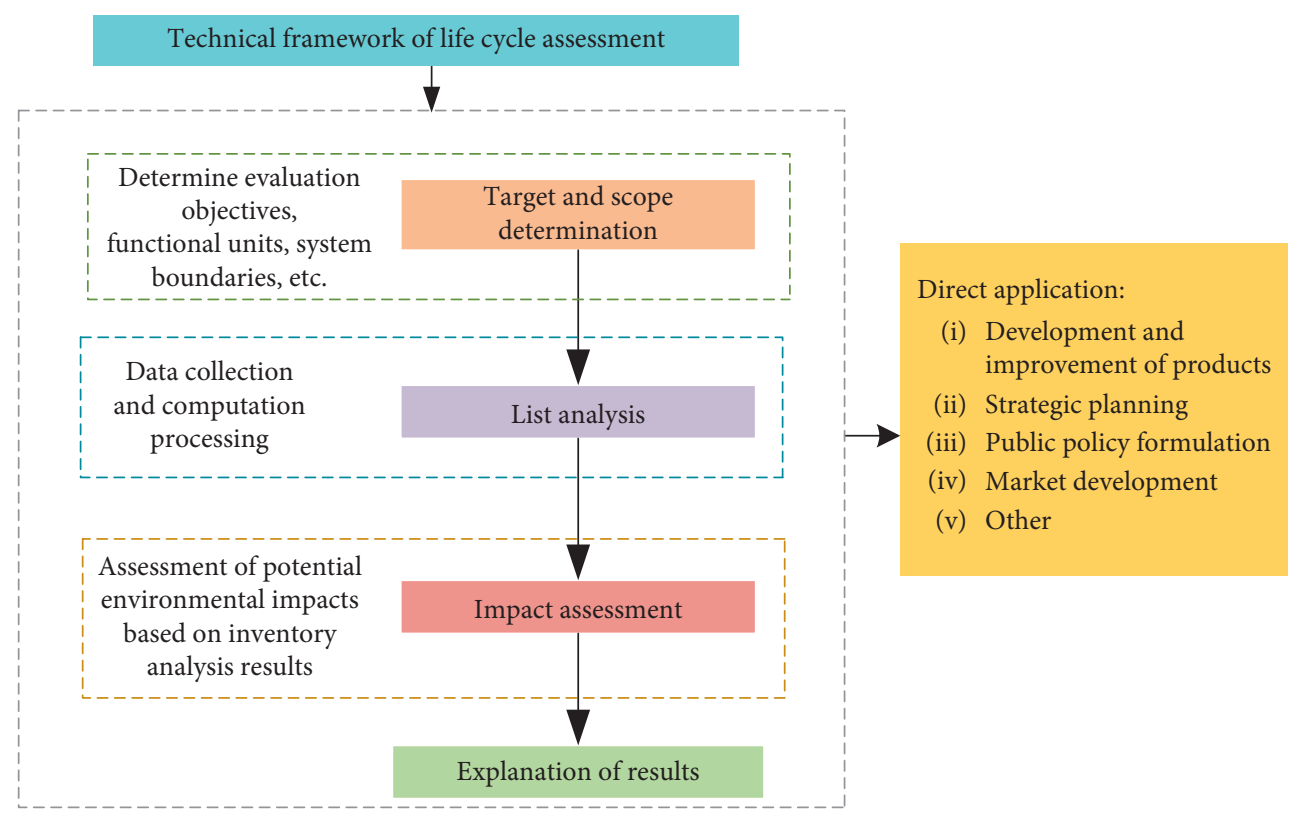

Figure 1: Technical framework for life-cycle assessment.

The specific treatment scenarios of waste straw are as follows:

Scenario 1. Particleboard is produced with waste straw (particleboard plant is located in Jilin province, China).

Scenario 2. The cement is used as the base material and straw fiber as reinforcing material to make straw cement-bonded particleboard (the plant is located in Jilin province, China).

Scenario 3. Direct combustion of straw is done for power generation (the power plant is located in Jilin province, China).

Scenario 4. Straw is open burnt (reference scenario).

\subsection{Scenario Description, System Boundary Determination,} and Inventory Analysis. The detailed process of each scenario is described in the following four subsections, in which different influencing factors are considered. The system boundaries are different for different scenarios, as shown in Figure 2, taking into account cradle to grave system boundaries.

2.3.1. Statement of Scenario 1. Straw is processed from the site by a 30-ton truck and transported to the local treatment site. The main mode of transportation is the highway, and diesel fuel is used. Assuming that $1.25 \mathrm{t}$ of straw is needed to produce $1 \mathrm{~m}^{3}$ straw particleboard and $1.5 \mathrm{t}$ of wood can produce $1 \mathrm{~m}^{3}$ wood particleboard. Assuming that the loss rate of straw is $1 \%, 1.26 \mathrm{t}$ straw is transported to the factory to produce $1 \mathrm{~m}^{3}$ straw particleboard and $1.51 \mathrm{t}$ wood to produce $1 \mathrm{~m}^{3}$ wood particleboard. The transportation distance is $40 \mathrm{~km}$, and the fuel consumption is $0.06 \mathrm{~L} /(\mathrm{km} \cdot \mathrm{t})$. The density of diesel oil is usually calculated as $0.85 \mathrm{~kg} / \mathrm{L}$. The fuel consumption of freight trucks is $2.5757 \mathrm{~kg}$ and $3.0908 \mathrm{~kg}$, respectively [40].

The natural air-dried straw is stored in the drying facility and treated on-site by using a forklift truck. The collected crop straws are cut into grass sections having a length of $20-40 \mathrm{~mm}$, and the moisture content of the straw is $12-20 \%$ [41]. Stone and gravel are removed by air separation and then the moisture content of the raw materials is controlled after $12-8 \%$ drying by using a pipeline air-dryer. The abovementioned straw segments are crushed by using a double-axle hammer mill with a screen mesh aperture of 5-10 $\mathrm{mm}$. The crushed fibers are screened into coarse and fine materials by using a wind screener. The moisture content of coarse materials and fine materials is controlled to be $8-14 \%$ and $10-14 \%$, respectively. The crude material is used as the core material, and the fine material is used as the surface material, which is sent to the storage silo for uniform mixing (adding MDI). The flame retardant additive and functional additive are added in the mixing process. The mixed material is laid into a slab through a paving machine, and after prepressing, it is subjected to a temperature of $190^{\circ} \mathrm{C}$ for 70 seconds, and the pressure is $5 \mathrm{MPa}$. The straw composite board can be obtained by later processing, including sawing and sanding. In the sanding process, it is necessary to remove the release layer to improve the surface quality and decorative performance of the strawboard. After the particleboard has been treated and cooled, it is stored in a place where temperature and humidity are appropriate.

Compared with the production process of wood board, the steps of the peeling machine, the peeling machine of logs, and the peeling-making of wood are omitted so that the energy consumption of these steps is saved. Among them, drying and hot pressing are the main energy use processes, while the fiber preparation, sorting, sizing, paving, preloading, cooling, trimming, sanding, and other processes consume little energy. The life cycles of $1 \mathrm{~m}^{3}$ straw particleboard and $1 \mathrm{~m}^{3}$ wood particleboard are compared, and the functional unit is $1 \mathrm{~m}^{3}$. Data of materials and energy consumption in transportation and production of particleboard are shown in Table 1. And the composition of straw 


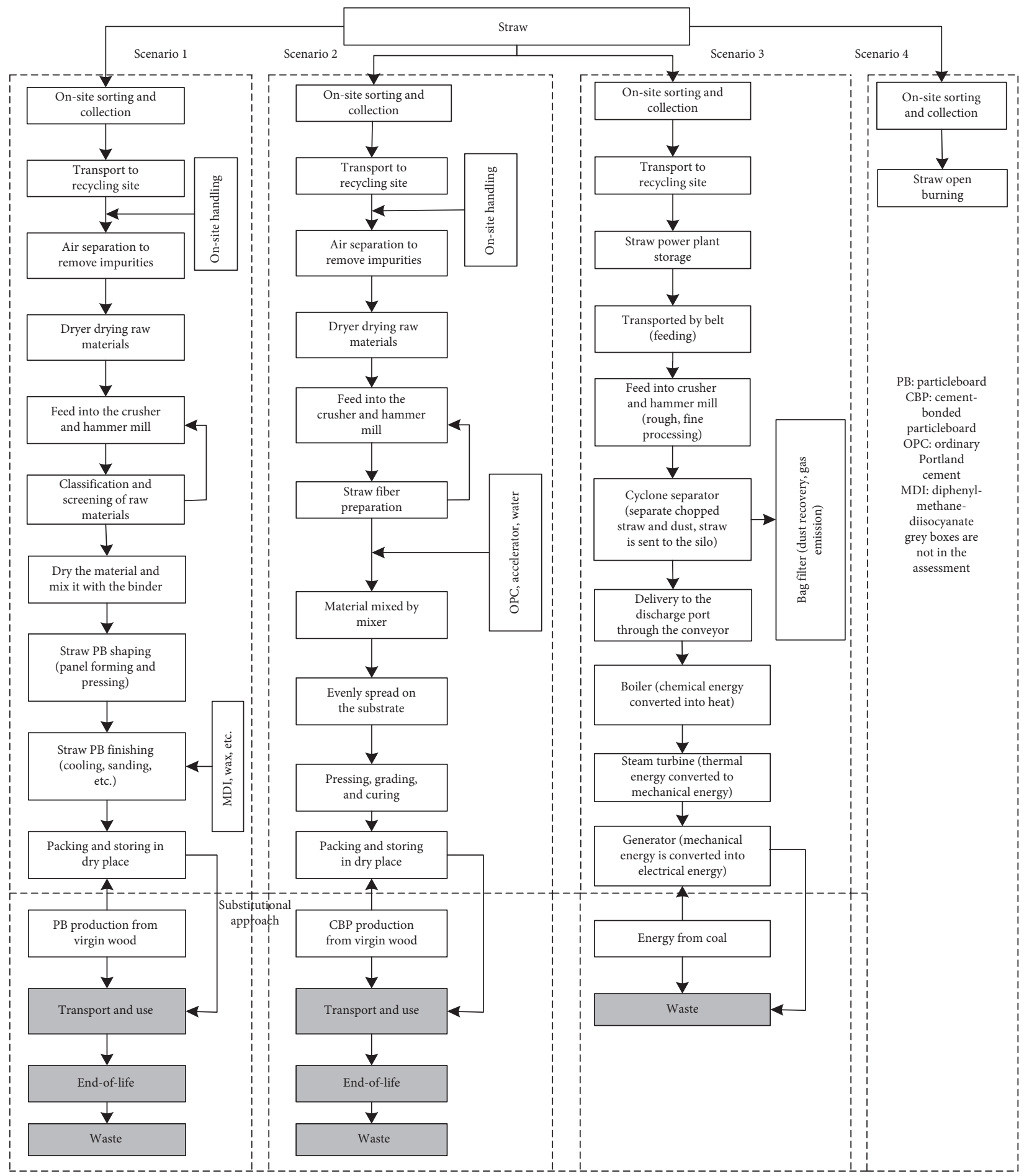

FIgURE 2: System boundary of straw resource utilization under different scenarios.

particleboard is shown in Table 2. The major equipment and energy used in the production process of Scenario 2 are shown in Table 3.

2.3.2. Statement of Scenario 2. Straw cement-bonded particleboard has good mechanical properties, mainly using straw fiber as reinforcing material and cement as cementing material, adopting a similar principle to cement particleboard.
The collected straw is cut into straw segments with a growth of less than $50 \mathrm{~mm}$ by using a cutting machine, processing into fibers by using a hammer shredder, and it is then sent to an air separator for air separation. The mixed stones are separated, and the wax in the straw is removed by referring to the traditional paper-making technology to make straw fibers. It is mixed with OPC and water, a few catalysts (about $4 \%$ of cement weight) into the wet mixture to accelerate the setting of the cement, and 
TABLE 1: LCI data for production of $1 \mathrm{~m}^{3}$ straw particleboard and wood particleboard.

\begin{tabular}{|c|c|c|}
\hline \multicolumn{3}{|l|}{$\begin{array}{l}\text { Process of production } \\
\text { Straw particleboard production }\end{array}$} \\
\hline $\begin{array}{l}\text { Straw particleboard production } \\
\text { Straw collection and processing } \\
\text { Straw transport to particleboard production site } \\
\text { Straw processing (preparation of straw, e.g., chips, planing, and screening) } \\
\text { Straw drying }\end{array}$ & $\begin{array}{l}40 \mathrm{~km} \text { by } 30 \mathrm{t} \text { trucks } \\
\text { Diesel: } 2.5757 \mathrm{~kg} \\
\text { Electricity: } 27.3 \mathrm{kWh} \\
\text { Electricity: } 20.4 \mathrm{kWh}\end{array}$ & {$[42,43]$} \\
\hline Other materials & & \\
\hline MDI, coatings, solid adhesives, production, and transportation & $\begin{array}{c}200 \mathrm{~km} \text { by } 30 \mathrm{t} \text { trucks } \\
\text { Diesel: } 0.34 \mathrm{~kg} \\
\text { Raw coal: } 16.64 \mathrm{~kg} \\
\text { Crude oil: } 25.14 \mathrm{~kg}\end{array}$ & {$[42-45]$} \\
\hline $\begin{array}{l}\text { Production processing (e.g., sheet paving, hot pressing, and cooling trimming) } \\
\text { Product completion and processing }\end{array}$ & $\begin{array}{c}\text { Electricity: } 50.3 \mathrm{kWh} \\
\text { Electricity: } 34 \mathrm{kWh} \\
\text { Diesel: } 1.35 \mathrm{~kg}\end{array}$ & $\begin{array}{c}{[44]} \\
{[42-44]}\end{array}$ \\
\hline $\begin{array}{l}\text { Wood particleboard production } \\
\text { Wood handling and transportation } \\
\text { Wood transport to particleboard production site } \\
\text { Wood treatment (processing and preparation of wood, e.g., chips, planing, and peeling) } \\
\text { Wood drying }\end{array}$ & $\begin{array}{c}40 \mathrm{~km} \text { by } 30 \mathrm{t} \text { trucks } \\
\text { Diesel: } 3.0908 \mathrm{~kg} \\
\text { Electricity: } 38.7 \mathrm{kWh}\end{array}$ & $\begin{array}{c}{[42,43]} \\
{[42,44,46]}\end{array}$ \\
\hline MDI, coatings, and solid adhesives, production, and transportation & $\begin{array}{l}\text { Electricity: } 33.8 \mathrm{kWh} \\
200 \mathrm{~km} \text { by } 30 \mathrm{t} \text { trucks } \\
\text { Diesel: } 0.29 \mathrm{~kg} \\
\text { Raw coal: } 13.961 \mathrm{~kg} \\
\text { Crude oil: } 22.043 \mathrm{~kg}\end{array}$ & {$[42-44]$} \\
\hline $\begin{array}{l}\text { Production processing (such as sheet paving, hot pressing, and cooling trimming) } \\
\text { Product completion and processing }\end{array}$ & $\begin{array}{c}\text { Electricity: } 48.2 \mathrm{kWh} \\
\text { Electricity: } 31.2 \mathrm{kWh} \\
\text { Diesel: } 1.1135 \mathrm{~kg}\end{array}$ & $\begin{array}{c}{[44]} \\
{[42,43]}\end{array}$ \\
\hline
\end{tabular}

TABLE 2: Composition of straw particleboard production and the process involved.

\begin{tabular}{lcc}
\hline Materials & Proportion $(\%)$ & Raw materials involved in the process \\
\hline Straw & 97.58 & Straw transport to site, straw drying, and straw processing \\
MDI & 1.95 & MDI production and transportation \\
Waterproof agent & 0.396 & Waterproof agent production and transportation \\
Mold dope & 0.074 & Mold dope production and transportation \\
Finished particleboard $\left(\mathrm{m} \mathrm{m}^{3}\right)$ & 100 & Board production processing, finishing process, and on-site handling \\
\hline
\end{tabular}

then it is fed into the air paver through the conveyor. After the mixture is paved by an air-flow paver, the cement straw cement-bonded particleboard is formed, which is stacked neatly by the manipulator on the bottom module of the clamping device. After stacking several pieces, the pressure module is pressed up. After being fed by the rolling table, the pressure is reached, and then the mold is pressed. Finally, it is sent to the drying room for heating and maintenance through the rolling table. After 6 hours of maintenance, it is sent to the unloading section. Mold unloading is completed and transferred by using a forklift to the stacking site for natural maintenance. Ultimately, after 30 days of sawing, sanding, warehousing, and storage, the final strength reached $95 \%$ and the slab can be released from the factory. Therefore, the water content of the final products is about $7.5-10 \%$, the optimum density of straw cement-bonded particleboard is about $1370 \mathrm{~kg} /$ $\mathrm{m}^{3}$, and the bending strength of 28 days is $11.8 \mathrm{MPa}$, in line with ISO standards [47]. Data of materials and energy consumption in transportation and production of cement particleboard are shown in Table 4 . And the composition of straw cement-bonded particleboard produced is shown in Table 5.

The pollutant data of electricity production in Table 6 are calculated based on the average energy consumption of China's power generation of $0.424 \mathrm{~kg}$ standard coal $/ \mathrm{kWh}$, which is equivalent to the calorific value of $4244 \mathrm{~kJ} / \mathrm{kg}$ of coal. The ash content is calculated as $20 \%$; and the $\mathrm{NO}_{2}$ and $\mathrm{SO}_{2}$ production in the power generation and transportation systems are calculated based on the corresponding average emission factors. All raw materials are mined with the same electricity consumption, without considering other pollutants. According to the data in Table 6, the corresponding environmental results can be calculated. The main equipment used in the production process of Scenario 1 and its energy consumption are shown in Table 3.

2.3.3. Statement of Scenario 3. Straw direct combustion power generation is a power generation method using crop straw as the main fuel. Moreover, the average sulfur content of straw is only 3.8 parts per thousand, which can replace 
TABLE 3: Major equipment and energy used in the production process of Scenarios 1, 2, and 3.

\begin{tabular}{|c|c|c|}
\hline Equipment & Function & Energy \\
\hline $\begin{array}{l}\text { Crusher, hammer mill } \\
(\text { Scenarios } 1,2,3)\end{array}$ & Preparation of fibers & Electrical energy \\
\hline Dryer (Scenarios 1, 2, 3) & Fiber drying & $\begin{array}{c}\text { Electrical energy, thermal } \\
\text { energy }\end{array}$ \\
\hline Sizing system (Scenarios 1, 2) & Sizing, waterproofing agent & Electrical energy \\
\hline Blender (Scenario 2) & Mixing fiber and cement & Electrical energy \\
\hline $\begin{array}{l}\text { Paving machine } \\
(\text { Scenarios } 1,2)\end{array}$ & Fiber pavement forming & Electrical energy \\
\hline Hot press (Scenarios 1, 2) & Compressed into board & $\begin{array}{l}\text { Electrical energy, thermal } \\
\text { energy }\end{array}$ \\
\hline $\begin{array}{l}\text { Sanding machine } \\
(\text { Scenarios } 1,2)\end{array}$ & Board sanding & Electrical energy \\
\hline $\begin{array}{l}\text { Sawing machine } \\
\text { (Scenarios } 1,2)\end{array}$ & Prepared specification board & Electrical energy \\
\hline $\begin{array}{l}\text { Blower, induced draft fan } \\
\text { (Scenarios } 1,2)\end{array}$ & Exhaust, ventilation & Electricity, gas \\
\hline $\begin{array}{l}\text { Supply air system } \\
\text { (Scenarios } 1,2)\end{array}$ & Transportation of fiber raw materials & Electrical energy \\
\hline $\begin{array}{l}\text { Cyclone separator } \\
\text { (Scenario 3) }\end{array}$ & Separation of straw and dust & Electrical energy \\
\hline Bag filter (Scenario 3) & Dust recovery, gas emissions & Electrical energy \\
\hline Conveyor (Scenario 3) & Conveying materials & Electrical energy \\
\hline Boiler (Scenario 3) & Convert chemical energy into thermal energy & $\begin{array}{c}\text { Chemical energy } \longrightarrow \text { thermal } \\
\text { energy }\end{array}$ \\
\hline Steam turbine (Scenario 3) & $\begin{array}{c}\text { Steam enters steam turbine adiabatic expansion to do work to convert } \\
\text { thermal energy into mechanical energy }\end{array}$ & $\begin{array}{l}\text { Thermal energy } \longrightarrow \\
\text { mechanical energy }\end{array}$ \\
\hline Generator (Scenario 3) & Converting mechanical energy into electricity & $\begin{array}{l}\text { Mechanical energy } \longrightarrow \\
\text { electrical energy }\end{array}$ \\
\hline
\end{tabular}

fossil energy, reduce greenhouse gas emissions, and produce fewer nitrogen oxides by low-temperature combustion [51]. Therefore, the flue gas after dust removal can be directly discharged into the atmosphere through the chimney without desulfurization $[52,53]$.

The straw is transported to the power generation enterprise through the main road by using a truck, and the fuel used is diesel. At the stage of straw transportation, the pollutant emissions are considered to be the emissions of diesel during production and combustion. According to the emission coefficient of diesel production and combustion, pollutant emissions during transportation can be calculated. The straw direct combustion power generation process is mainly divided into three parts: the collection and treatment of straw, the pretreatment of straw, and the last step is combustion power generation. Straw pretreatment is done after straw collection and treatment. The pretreatment of the power plant is mainly performed to decompose and crush the collected straw. Usually a complete set of equipment is used, including crusher, conveyor, and dust collector (with a bag dust collector at the tail of the boiler). Finally, the power plant pretreatment data and biomass (straw) power generation index are calculated based on the survey, and the direct-fired power generation system is analyzed and calculated. With reference to the literature and specifications, the energy released by burning $1 \mathrm{t}$ of straw for power generation is statistically analyzed and compared with common power generation methods (coal power generation is divided into three steps: coal mining and washing, coal transportation and storage, and coal power generation), and from [36], the functional units are 1 ton. Data of materials and energy consumption in transportation and production of power generation are shown in Table 7. Table 3 shows the main equipment and energy consumption used in the production process of Scenarios 1,2 , and 3 .

2.3.4. Statement of Scenario 4 (Reference Scenario). Straw directly burned outdoors will cause serious air pollution problems. Besides, the proportion of straw open burning has a certain relationship with crop yield, geographical location, and income level of residents. In large agricultural provinces with high crop yield, farmers have a higher tendency to choose straw burning in the open air. Secondly, due to the lack of heating in winter, the demand for straw as fuel is insufficient and the possibility of open burning is higher. Open-air incineration of crop straw will emit gas pollutants, resulting in a sharp decline in air quality.

By collecting the existing emission test results, the environmental impact of $1 \mathrm{t}$ straw open-air incineration treatment was evaluated. And the atmospheric pollutant emission factors of various straws were obtained and the average values were taken [56-59]. The results of the straw open burning incineration factors are shown in Table 8.

2.4. Impact Assessment and Explanation. In this study, global warming potential (GWP) and nonrenewable energy consumption are used as impact assessment criteria. It is 
TABLE 4: LCI data for production of $1 \mathrm{~m}^{3}$ straw cement-bonded particleboard and wood cement-bonded particleboard.

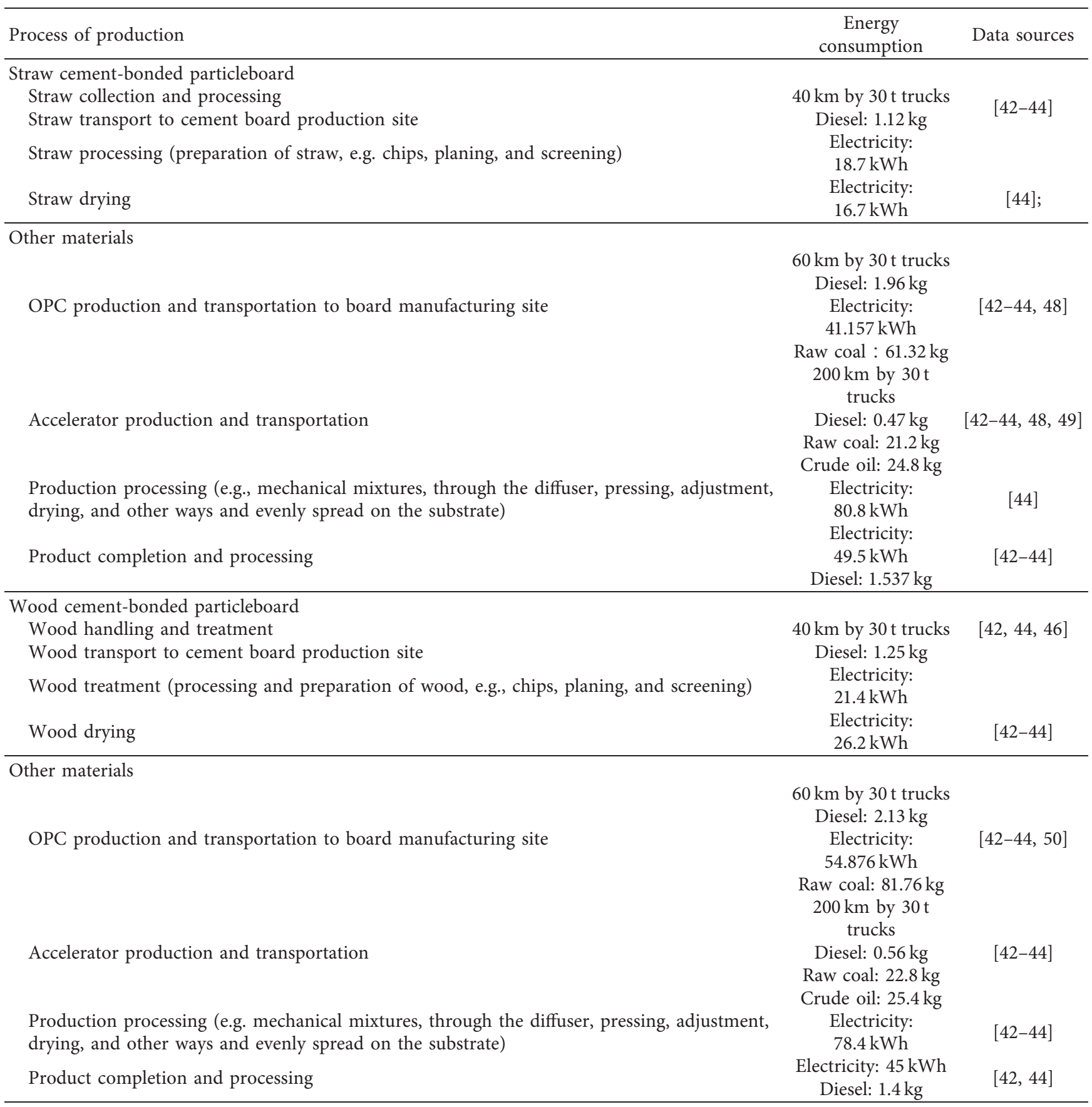

TABLE 5: Composition of straw cement-bonded particleboard and the process involved.

\begin{tabular}{lcc}
\hline Materials & $\begin{array}{c}\text { Proportion } \\
(\%)\end{array}$ & Raw materials involved in the process \\
\hline OPC & 53 & OPC production and transportation \\
Straw fiber & 38 & Straw transport to site, straw drying, and straw processing \\
Accelerator $\left(\mathrm{CaCl}_{2}\right)$ & 5 & Accelerator production and transportation \\
Waterproof agent & 1.5 & Waterproof agent production and transportation \\
Adhesive & 2.5 & Mold dope production and transportation \\
$\begin{array}{l}\text { Finished cement composite board } \\
\left(1 \mathrm{~m}^{3}\right)\end{array}$ & 100 & Cement-bonded particleboard production processing, finishing process, and on- \\
site handling
\end{tabular}


TABLE 6: Environmental data for utility systems and cement production.

\begin{tabular}{|c|c|c|c|c|c|c|}
\hline & Energy consumption & $\mathrm{CO}_{2}(\mathrm{~kg})$ & $\mathrm{CO}(\mathrm{kg})$ & $\mathrm{C}_{\mathrm{x}} \mathrm{H}_{\mathrm{y}}(\mathrm{kg})$ & $\mathrm{NO}_{\mathrm{x}}(\mathrm{kg})$ & $\mathrm{SO}_{2}(\mathrm{~kg})$ \\
\hline Electricity (kWh) & $\begin{array}{c}\text { Standard coal: } 0.424 \mathrm{~kg} \\
0.0124 \mathrm{GJ}\end{array}$ & 0.938 & 0.00004 & 0.000072 & 0.0051 & 0.00112 \\
\hline Transport $(30 \mathrm{t} \cdot \mathrm{km})$ & $\begin{array}{c}\text { Diesel: } 0.06 \mathrm{~L} /(\mathrm{km} \cdot \mathrm{t}) \\
0.02142 \mathrm{GJ}\end{array}$ & 1.6614 & 0.0106 & 0.000094 & 0.00637 & 0.000359 \\
\hline Coal $\left(10^{3} \mathrm{~kg}\right)$ & Electricity: $13.89 \mathrm{kWh}$ & - & - & - & - & - \\
\hline Cement mining $\left(10^{3} \mathrm{~kg}\right)$ & Electricity: $13.89 \mathrm{kWh}$ & - & - & - & - & - \\
\hline Cement manufacturing $\left(10^{3} \mathrm{~kg}\right)$ & $\begin{array}{l}\text { Electricity: } 123.3 \mathrm{kWh} \\
\text { Coal: } 204.4 \mathrm{~kg}\end{array}$ & 885 & 0.0115 & 0.0273 & 1.533 & 0.354 \\
\hline
\end{tabular}

TABLe 7: LCI data for $1 \mathrm{t}$ straw direct combustion and coal-fired power generation.

\begin{tabular}{|c|c|c|}
\hline Process of production & Energy consumption & Data sources \\
\hline \multicolumn{3}{|l|}{ Straw direct combustion power generation } \\
\hline Straw collection and processing & $40 \mathrm{~km}$ by $30 \mathrm{t}$ trucks & {$[42,43]$} \\
\hline \multirow{2}{*}{ Straw transport to power plant } & Electricity: $30 \mathrm{kWh}$ & {$[42,44]$} \\
\hline & Diesel: $2.05 \mathrm{~kg}$ & {$[42,43]$} \\
\hline $\begin{array}{l}\text { Straw pretreatment (crushing and } \\
\text { drying) }\end{array}$ & $\begin{array}{l}\text { Electricity: } 21.2 \mathrm{kWh} \\
\text { Raw coal: } 44.6 \mathrm{~kg}\end{array}$ & {$[42,43,54,55]$} \\
\hline Combustion power generation & $\begin{array}{c}\begin{array}{c}\text { Provided by the system's own power generation, no energy consumption is } \\
\text { required }\end{array} \\
\text {. }\end{array}$ & \\
\hline \multicolumn{3}{|l|}{ Coal-fired power generation } \\
\hline Coal production and processing & $40 \mathrm{~km}$ by $30 \mathrm{t}$ trucks & {$[54,55]$} \\
\hline $\begin{array}{l}\text { Coal preparation (coal mining and } \\
\text { washing) }\end{array}$ & Electricity: $225 \mathrm{kWh}$ & {$[42,43,54,55]$} \\
\hline Coal transport to power plant & Diesel: $2.04 \mathrm{~kg}$ & {$[42,43]$} \\
\hline Combustion power generation & $\begin{array}{c}\begin{array}{c}\text { Provided by the system's own power generation, no energy consumption is } \\
\text { required }\end{array}\end{array}$ & \\
\hline
\end{tabular}

TABLE 8: Emission factors of straw open burning.

\begin{tabular}{lccccccc}
\hline \multirow{2}{*}{ Crops } & \multicolumn{7}{c}{ Emission factors $\left(\mathrm{g} \cdot \mathrm{kg}^{-1}\right)$} \\
& $\mathrm{CO}_{2}$ & $\mathrm{CH}_{4}$ & $\mathrm{CO}$ & $\mathrm{NO}_{\mathrm{x}}$ & $\mathrm{SO}_{2}$ & $\mathrm{NH}_{3}$ & $\mathrm{PM}$ \\
\hline Rice & 1460.00 & 3.20 & 34.70 & 3.10 & 2.00 & 0.78 & 12.95 \\
Wheat & 1460.00 & 3.40 & 60.00 & 3.30 & 0.85 & 0.37 & 7.60 \\
Maize & 1350.00 & 4.40 & 53.00 & 4.30 & 0.44 & 0.68 & 11.70 \\
Average value & 1423.33 & 3.67 & 49.23 & 3.57 & 1.10 & 0.61 & 10.75 \\
\hline
\end{tabular}

noteworthy that the scenarios studied are modeled using eBalance software and the CLCD database. Generally, a type of environmental impact is affected by several different pollutants, so the input of substances and the discharge of pollutants need to be classified according to the type of environmental impact, and then the potential of environmental impact is calculated, which can be estimated using (1) and (2) Finally, according to the functional unit, the environmental impact and energy consumption in different situations are compared, and the reasons are analyzed. Besides, both straw and wood will produce dust in the crushing process, so the impact of dust is not considered. Using Oracle Crystal Ball software, we simulated the changes of key parameters in the range of $( \pm 20 \%)$ for 1 million times and obtained the contribution rate of key parameters to the environmental performance of different scenarios.

Environmental impact potential (EIP) is the summation of all associated environmental emission impacts across the system and is expressed as

$$
E_{P}(m)=\sum E_{P}(m)_{n}=\sum\left[Q(m)_{n} \times E_{f}(m)_{n}\right],
$$

where $E_{P}(m)$ is the $m$ th environmental impact potential in the product life cycle, $E_{P}(m)_{n}$ is the $m$ th environmental impact potential of the $n$th emissions, $Q(m)_{n}$ is the $n$th emissions, and $E_{f}(m)_{n}$ is the $m$ th environmental impact equivalent factor of the $n$th emissions. Finally, the potential impacts of various environmental impacts are integrated.

The formula for calculating the benchmark value of environmental impact standardization is as follows:

$$
N E_{P}(m)=\frac{E_{p}(m)}{E_{R}(m)},
$$

where $N E_{P}(m)$ is the standardized value of the $m$ th environmental impact potential, $E_{P}(m)$ is the $m$ th environmental impact potential, and $E_{R}(m)$ is the per capita potential of social-environmental impact in the base year.

\section{Results and Discussion}

3.1. Discovery and Discussion of Scenario 1. The greenhouse gas (GHG) emissions and nonrenewable energy consumption of $1 \mathrm{~m}^{3}$ straw particleboard and wood particleboard are compared in Figures 3 and 4. It can be found that about $600 \mathrm{~kg} \mathrm{CO} 2$ eq GHG emission is generated in the production process of $1 \mathrm{~m}^{3}$ straw particleboard, while about $640 \mathrm{~kg} \mathrm{CO}$ eq GHG emission is related to the $1 \mathrm{~m}^{3}$ wood particleboard production (Figure 3). For straw or wood particleboard, the contribution to total emissions is, in turn, the production 


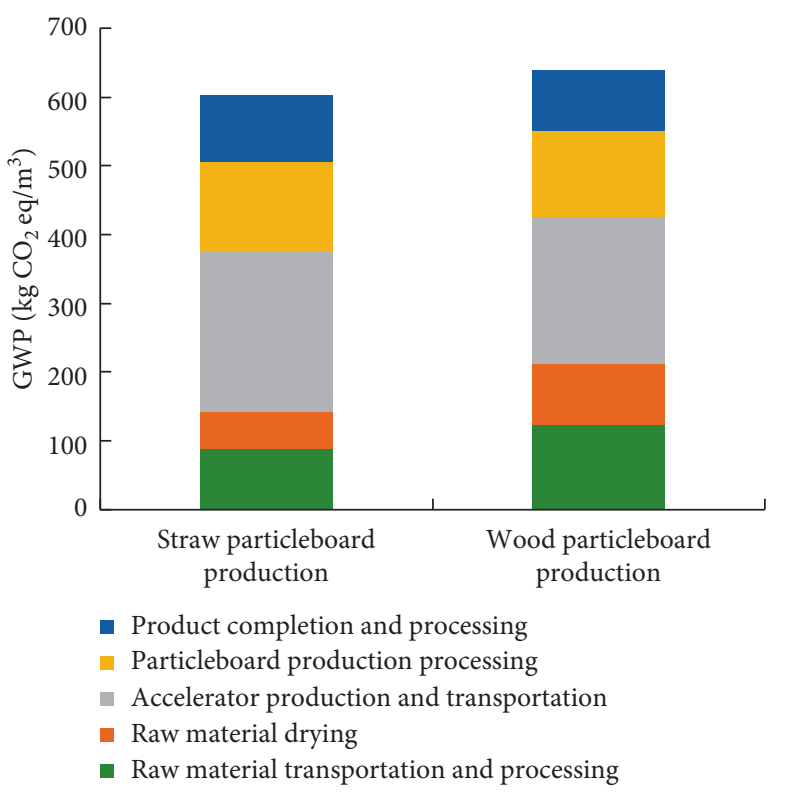

FIGURE 3: Contribution of particleboard production process to GWP impact.

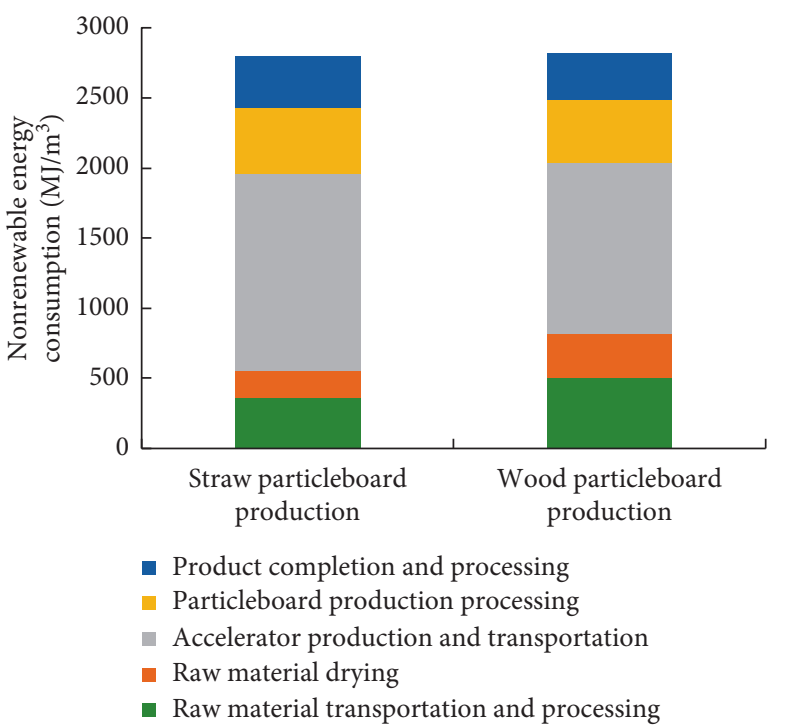

Figure 4: Contribution of particleboard production process to nonrenewable energy consumption.

and transportation of other materials such as accelerators, production, and processing (including plate paving, hot pressing, cooling and trimming) and transportation and processing of raw materials (including collection and transportation of raw materials, finishing, and drying). Similarly, the production of $1 \mathrm{~m}^{3}$ straw particleboard consumes about $2700 \mathrm{MJ}$ of nonrenewable energy, and about $2800 \mathrm{MJ}$ is related to $1 \mathrm{~m}^{3}$ particleboard produced with virgin wood (Figure 4).

It can be seen from Figures 3 and 4 that the ratio of wood particleboard to straw particleboard is higher in raw material processing and drying because the moisture content of raw wood is higher. The collection, transportation, and drying of wood greatly increase greenhouse gas emissions and resource consumption in particleboard production, and the drying process needs to make the moisture content below $12 \%$ to improve process efficiency and board quality. Besides, there are also significant differences in the transportation and processing of two different raw materials. Comparing straw particleboard with wood particleboard, it is found that the greenhouse gas emissions of straw particleboard are reduced by about 7\% (Figure 3). Similarly, straw particleboard reduced nonrenewable energy consumption by about $4 \%$ (Figure 4 ), which might be due to the fact that straw particleboard omitted the steps of the peeling machine, and peeling to make wood, which saved the energy consumption of these two steps compared with the production process of wood board (Table 9).

Juan et al. [33] proposed that, according to the life-cycle assessment (LCA) model, MDF applications could save $193-439 \mathrm{~kg}$ of $\mathrm{CO}_{2}$ equivalent of greenhouse gases (per $700 \mathrm{~kg}$ of bales of straw). The application of MDF could avoid the reduction of greenhouse gas emissions by about $36 \%$. Although energy and greenhouse gas emissions might be affected by the moisture content, transportation conditions, and equipment of straw in different regions, the results obtained in this study were consistent with the above results.

3.2. Discovery and Discussion of Scenario 2. Given the data collected in Scenario 2, the results of LCA are shown in Figures 5 and $6.1 \mathrm{~m}^{3}$ of cement-bonded particleboard releases about $980 \mathrm{~kg} \mathrm{CO}$ eq GHGs, while wood cementbonded particleboard produces about $1100 \mathrm{~kg} \mathrm{CO}_{2}$ eq GHGs. Straw cement-bonded particleboard reduces the greenhouse gas equivalent of about $120 \mathrm{~kg} \mathrm{CO}$ eq GHGs compared with wood cement-bonded particleboard. In straw cement-bonded particleboard production, raw material transportation and treatment accounts for $10 \%$ of greenhouse gas emissions, OPC production machine transportation account for $48 \%$, production process accounts for $35 \%$, and chemical catalyst accounts for $7 \%$. For straw cement-bonded particleboard, cement production and transportation contribute most to total emissions. The production and transportation of OPC in wood cementbonded particleboard accounted for $51 \%$ of the total, which is due to the largest amount and proportion of cement used in the production of cement-bonded particleboard.

Likewise, the production of $1 \mathrm{~m}^{3}$ wood cement-bonded particleboard consumes about $5500 \mathrm{MJ}$ of nonrenewable energy, which is higher (about 15\%) than the straw cementbonded particleboard production. In the production of straw cement-bonded particleboard, the transportation and treatment of raw materials account for $8 \%$ of nonrenewable energy consumption, the production and transportation of OPC account for $36 \%$, the production process accounts for $26 \%$, and the use of chemical catalysts accounts for $30 \%$. For straw cement-bonded particleboard, the most important contribution to total emissions is the production and transportation of OPC, accounting for $41 \%$ of the total. Therefore, it is observed that the production of straw cement-bonded particleboard has a less environmental impact. 
TABle 9: Comparative contribution to the production of straw and wood particleboard.

\begin{tabular}{lcccc}
\hline \multirow{2}{*}{ Processes } & \multicolumn{2}{c}{ GHG emission (\%) } & \multicolumn{2}{c}{ Nonrenewable energy consumption (\%) } \\
& Straw particleboard & Wood particleboard & Straw particleboard & Wood particleboard \\
\hline Raw materials transportation and processing & 14.77 & 19.47 & 12.92 & 17.79 \\
Raw material drying & 8.71 & 13.63 & 6.72 & 11.06 \\
Accelerator production and transportation & 38.88 & 33.62 & 50.53 & 43.50 \\
Particleboard production processing & 21.48 & 19.43 & 16.57 & 15.76 \\
Product completion and processing & 16.16 & 13.85 & 13.26 & 11.89 \\
Total & 100.00 & 100.00 & 100.00 & 100.00 \\
\hline
\end{tabular}

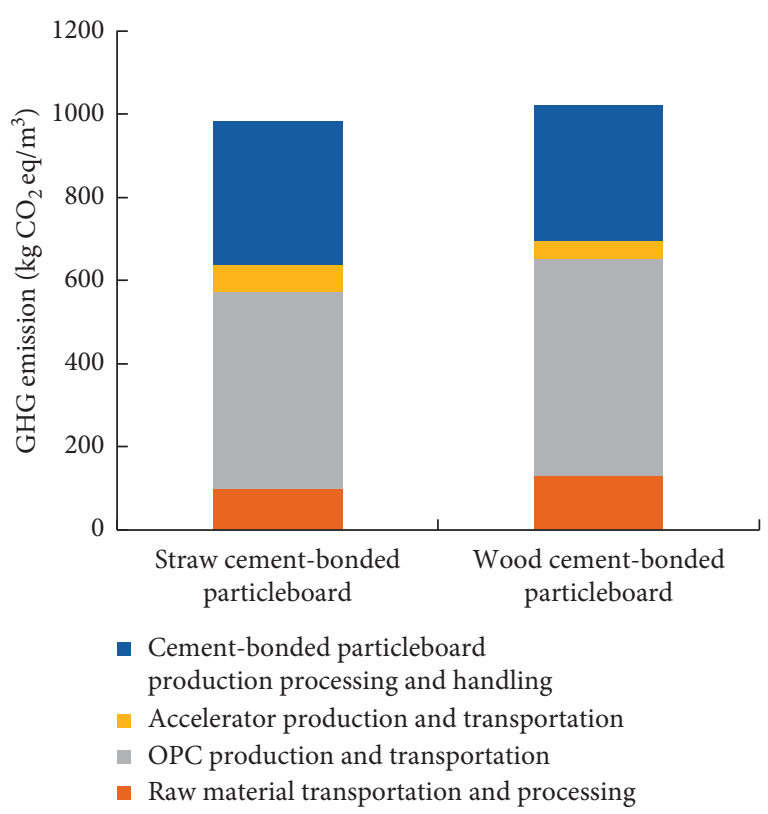

FIGURE 5: Contribution of cement-bonded particleboard production process to GWP impact.

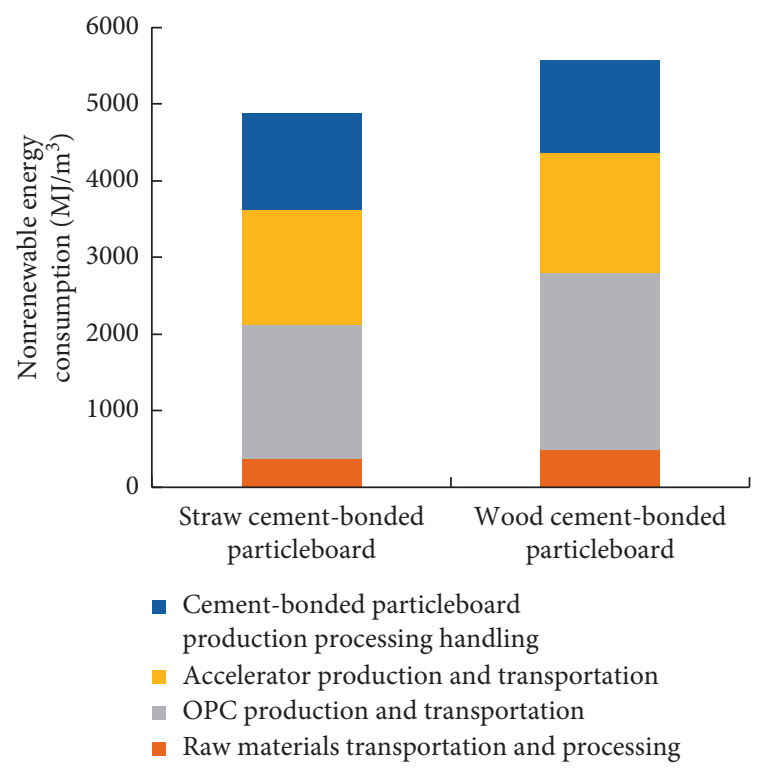

FIgURE 6: Contribution of cement-bonded particleboard production process to nonrenewable energy consumption.
The comparative analysis of the production of straw cementbonded particleboard and wood cement-bonded particleboard is shown in Table 10.

Eternit [60] demonstrated the energy consumption and greenhouse gas emissions of cement particle board (for environmental product declarations). The study found that producing 1 ton of CBP and OPC (excluding carbon fixation) from logs in Germany consumed about 7100-14000 MJ of nonrenewable energy and emitted about $800-1100 \mathrm{~kg}$ of carbon dioxide equivalent greenhouse gases. Although there was no LCA-related research on straw cement cementbonded particleboard, the related research of wood cement particleboard provides a reference.

3.3. Discovery and Discussion of Scenarios 3 and 4. In this study, the life cycle of a ton of straw and a ton of coal power generation are compared and analyzed, and the results of GWP and total emissions of nonrenewable resources consumption in the power generation process are compared, as shown in Figures 7 and 8. As can be seen from Figure 7, the GHG emissions of $1 \mathrm{t}$ straw direct combustion power generation are approximately $2100 \mathrm{~kg} \mathrm{CO}_{2}$ eq GHGs, while that of $1 \mathrm{t}$ coal-fired power generation is approximately $3000 \mathrm{~kg} \mathrm{CO} 2$ eq. The GHG emissions of straw direct combustion power generation are about 30\% lower than that of coal-fired power generation. In straw direct combustion power generation, the straw collection and transportation accounts for $5 \%$ of the total GHG emissions, the pretreatment of straw (crushing, drying, and shaping) accounts for $14 \%$, and the combustion power generation accounts for $81 \%$. For straw direct combustion power generation, the electric power generation process contributes most to the total emissions. For coal-fired power generation, coal treatment, transportation and storage, and coal-fired power generation accounted for $19 \%, 1 \%$, and $80 \%$ of the total emissions, respectively. The power generation process accounted for the largest proportion, and the pollutant emissions are large, which would pollute the environment (Table 11).

From Figure 8, it can be seen that $1 \mathrm{t}$ straw direct combustion power generation consumes about $1400 \mathrm{MJ}$ nonrenewable resources, which is about $36 \%$ lower than coal-fired power. In straw direct combustion power generation, straw collection and transportation, straw pretreatment, and combustion power generation accounted for 
TABLE 10: Comparative contribution to the production of straw and wood cement-bonded particleboard.

\begin{tabular}{|c|c|c|c|c|}
\hline \multirow[b]{2}{*}{ Processes } & \multicolumn{2}{|c|}{ GHG emission (\%) } & \multicolumn{2}{|c|}{ Nonrenewable energy consumption (\%) } \\
\hline & $\begin{array}{l}\text { Straw cement-bonded } \\
\text { particleboard }\end{array}$ & $\begin{array}{l}\text { Wood cement-bonded } \\
\text { particleboard }\end{array}$ & $\begin{array}{l}\text { Straw cement-bonded } \\
\text { particleboard }\end{array}$ & $\begin{array}{l}\text { Wood cement-bonded } \\
\text { particleboard }\end{array}$ \\
\hline $\begin{array}{l}\text { Raw materials transportation and } \\
\text { processing }\end{array}$ & 5.73 & 6.28 & 4.51 & 4.51 \\
\hline Raw material drying & 4.37 & 6.59 & 3.15 & 4.35 \\
\hline $\begin{array}{l}\text { OPC production and } \\
\text { transportation }\end{array}$ & 48.39 & 50.91 & 35.71 & 41.49 \\
\hline $\begin{array}{l}\text { Accelerator production and } \\
\text { transportation }\end{array}$ & 6.25 & 4.17 & 30.71 & 28.11 \\
\hline $\begin{array}{l}\text { Cement-bonded particleboard } \\
\text { production processing }\end{array}$ & 21.16 & 19.73 & 15.24 & 13.00 \\
\hline $\begin{array}{l}\text { Product completion and } \\
\text { processing }\end{array}$ & 14.10 & 12.32 & 10.68 & 8.54 \\
\hline Total & 100.00 & 100.00 & 100.00 & 100.00 \\
\hline
\end{tabular}

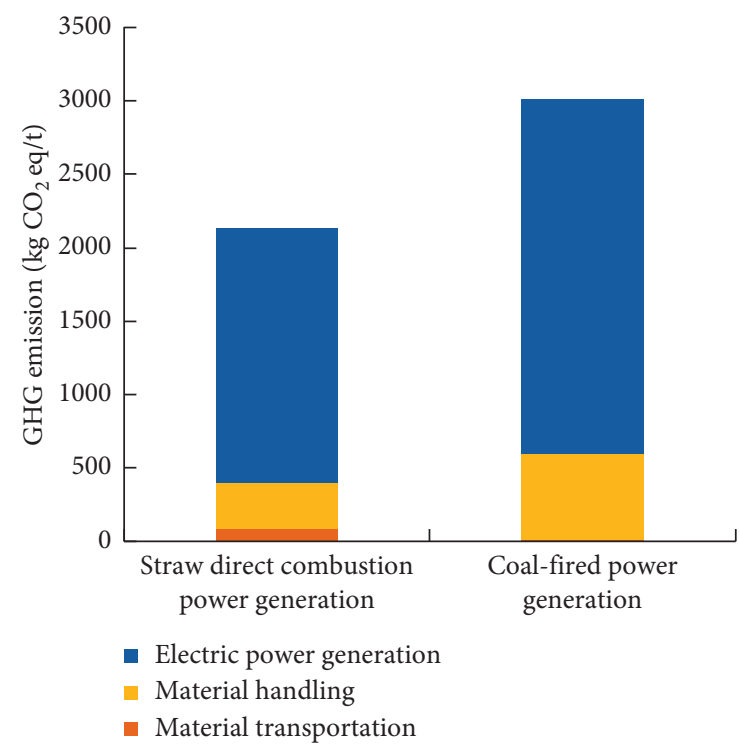

FIGURE 7: Contribution of different ways of power generation to GWP impact.

$25 \%, 75 \%$, and 0 of the total consumption, respectively. For straw direct combustion power generation, the straw pretreatment process contributes the most to the total emissions, including the smashing, drying, and shaping of straw. Similarly, coal mining and washing, transportation and storage, and coal-fired power generation accounted for $95 \%$, $5 \%$, and $0 \%$ of the total emissions, respectively. The coal mining and washing process accounted for the largest proportion. Coal mining and washing generally extracted coal from the producing area and removed impurities from coal, and the main energy consumption is electricity (Table 11).

Liu et al. [61] proved that if there were 400 million tons of waste straw in China could replace 200 million tons of coal, then 291 watt-hours (TWh) of straw could be produced each year, which saved 193 million tons of $\mathrm{CO}_{2}$ annually. Shafie et al. [30] calculated that straw power generation could save about $1.79 \mathrm{~kg} / \mathrm{kWh}$ of greenhouse gas emissions compared to coal-fired power generation and natural gas

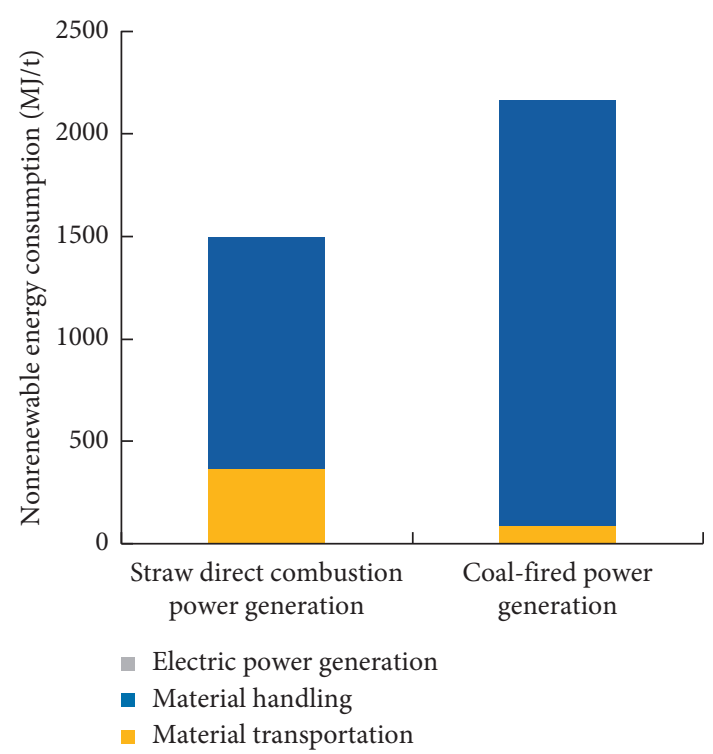

FIgURE 8: Contribution of different ways of power generation to nonrenewable energy consumption.

power generation. The improvement of energy efficiency of the straw pretreatment equipment will lead to a reduction in greenhouse gas emissions and energy consumption in the life cycle of straw power generation. Although the energy consumption and $\mathrm{CO}_{2}$ emissions were severely affected by local energy sources and equipment, the results obtained in this study were consistent with the above findings.

Scenario 4 (straw open burning), rice, corn, and wheat straw are the main sources of emissions from the open burning of straw in China. Due to the differences in crop yield and the proportion of straw open burning and combustion efficiency, the contribution rates of different crop types to pollutant emissions are also different. Therefore, the emission factor is taken as the average value of three main crop types. The carbon emissions of straw incineration in the open are very high, with $\mathrm{CO}_{2}$ as high as $1423 \mathrm{~g} / \mathrm{kg}$, followed by $49 \mathrm{~g} / \mathrm{kg}$ of CO gas and $10 \mathrm{~g} / \mathrm{kg}$ of PM. These three kinds of gases are high pollutant gases, especially $\mathrm{CO}_{2}$, which is much higher than other pollutants. It is estimated that the GHG 
TABLE 11: Comparative contribution analysis for different electric power generation processes.

\begin{tabular}{|c|c|c|c|c|}
\hline \multirow[b]{2}{*}{ Processes } & \multicolumn{2}{|c|}{ GHG emission (\%) } & \multicolumn{2}{|c|}{ Nonrenewable energy consumption (\%) } \\
\hline & $\begin{array}{c}\text { Straw direct combustion power } \\
\text { generation }\end{array}$ & $\begin{array}{l}\text { Coal-fired power } \\
\text { generation }\end{array}$ & $\begin{array}{l}\text { Straw direct combustion power } \\
\text { generation }\end{array}$ & $\begin{array}{l}\text { Coal-fired power } \\
\text { generation }\end{array}$ \\
\hline Material transportation & 4.32 & 0.49 & 24.40 & 4.03 \\
\hline Material handle & 14.26 & 19.26 & 75.60 & 95.97 \\
\hline Electric power generation & 81.42 & 80.25 & 0 & 0 \\
\hline Total & 100.00 & 100.00 & 100.00 & 100.00 \\
\hline
\end{tabular}

emission of about $2642 \mathrm{~kg} \mathrm{CO} 2$ eq is related to $1 \mathrm{t}$ straw burning in the open air, which is much higher than the other three scenarios. Compared with open burning, the biggest advantage of strawboard and straw power generation is to reduce carbon emissions and PM emissions.

\subsection{Comparative Analysis of Different Straw Management} Strategies. The difference of nonrenewable energy consumption and gas emission indices under different straw resource utilization scenarios is compared in Figures 9 and 10. The environmental impact of different management scenarios is shown in Table 10. All are discussed under the functional unit of 1-ton straw. Figure 9 shows that the nonrenewable energy consumption of straw cement-bonded particleboard is the highest and straw direct combustion power generation consumption is the lowest mainly because of the large proportion of OPC, accelerators, and other materials in the production of straw cement-bonded particleboard, which consumes more energy.

$\mathrm{CO}_{2}, \mathrm{CH}_{4}, \mathrm{~N}_{2} \mathrm{O}$, and so on are the main gases causing GWP. $\mathrm{SO}_{2}$ and $\mathrm{NO}_{x}$ are the main gases causing the acidification potential (AP). The emission index of open burning of $\mathrm{CO}_{2}, \mathrm{SO}_{2}$, or other gases is much higher than that of other scenarios. Straw direct combustion power generation is much larger than that of straw particleboard and straw cement-bonded particleboard. The emission index is mainly because the straw combustion process has the greatest impact on the environment in direct combustion power generation (Figure 10). Compared with other scenarios, the GWP and AP comparisons of numerical values are straw open burning $>$ straw direct combustion power generation $>$ straw cement-bonded particleboard $>$ straw particleboard. The greenhouse effect and acidification effect of straw open burning are far greater than those of other scenarios, but the impact of straw particleboard and straw cement-bonded particleboard on the environment is relatively small (Table 12).

According to the related research, Scenarios 1, 2, and 3 are feasible in the technology of using the waste straw $[4,22,62]$. It is most advantageous to convert waste straw into green products and produce them in nearby factories because it reduces the long-distance supply chain and its associated impacts. Therefore, straw open burning has caused great environmental pollution in the light of greenhouse gas emissions, acidification effects, and particulate matter emissions. Making straw into board or fuel can

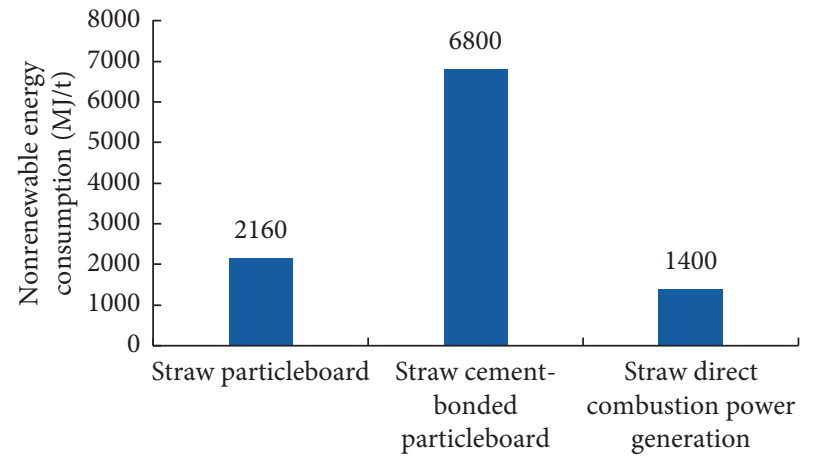

FIGURE 9: Comparison of nonrenewable energy consumption in Scenarios 1, 2, and 3 .

improve the environmental impact. From the perspective of environment, straw building materials have little environmental influence and can be widely used.

3.5. Sensitivity Analysis. Using Oracle Crystal Ball software, the key parameters are changed within $\pm 20 \%$ for 1 million times and obtained the contribution rate of key parameters to the environmental performance under different scenarios as shown in Figure 11. From the figure, we can see that the power consumption of the molding process, the distance of straw transportation, and the power consumption in the shaping the process are the three main elements affecting the environmental performance of Scenario 1. The total contribution rate of the three factors to GWP is $79.4 \%$. The contribution rate of the power consumption in the shaping process to the environmental emission change of the system reaches $36.7 \%$. In Scenario 2, the power consumption of the shaping process, straw transportation distance, and OPC transportation distance are the primary factors. The total contribution proportion of the three factors to GWP is $85.3 \%$. Among them, the contribution rate of power consumption in shaping process to the change of system environment emission is 33.7\%. In Scenario 3, the contribution rates of straw pretreatment power consumption and straw transport distance are $58.3 \%$ and $41.7 \%$, respectively.

Reducing the impact of raw material consumption is comprehensive and can reduce the input of straw transportation and pretreatment process at the same time. Therefore, it is obliged to control the water content of raw stocks, reduce the loss of raw material collection, and 

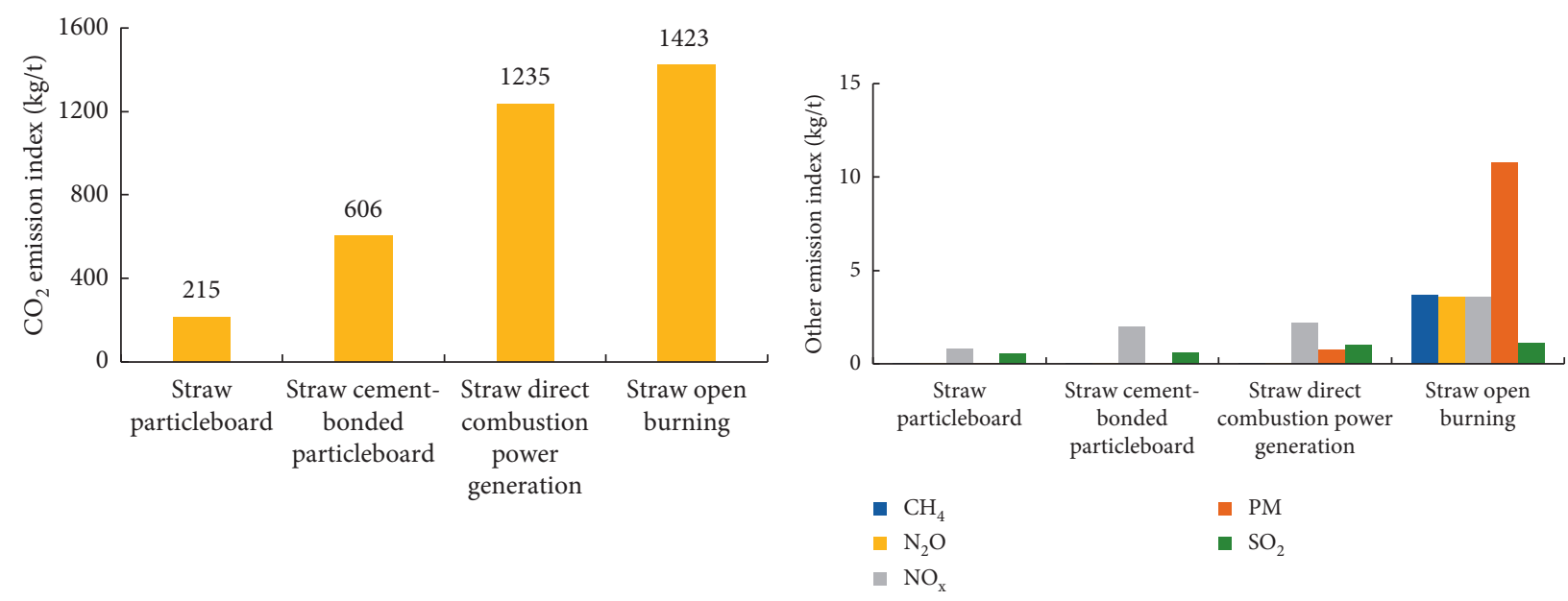

(a)

(b)

Figure 10: Comparisons of gas emission index under different scenarios: (a) comparisons of $\mathrm{CO}_{2}$ emission index and (b) comparisons of other gas emission index.

TABLE 12: Comparison of environmental impact trends among different management scenarios.

\begin{tabular}{lcc}
\hline Scenario & GWP $(\mathrm{kg} \mathrm{CO} 2$ eq/t) & AP $\left(\mathrm{kg} \mathrm{SO} \mathrm{S}_{2}\right.$ eq/t) \\
\hline 1 & $\longrightarrow 2000$ & $\longrightarrow 2.5$ \\
2 & $\longrightarrow 1620$ & $\longrightarrow 1.6$ \\
3 & $\longrightarrow 600$ & 3.1 \\
4 & 2600 & 3.6 \\
\hline
\end{tabular}

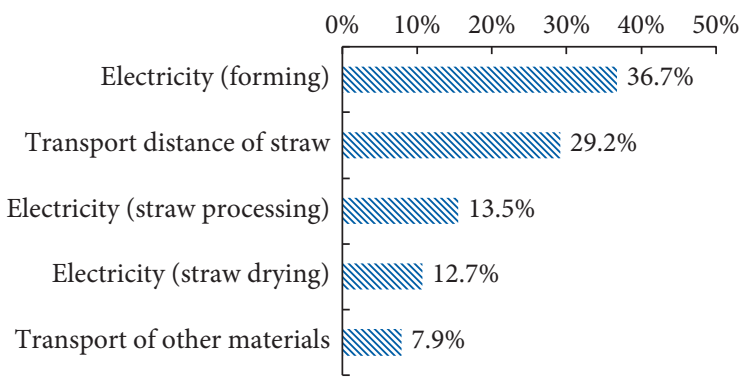

(a)

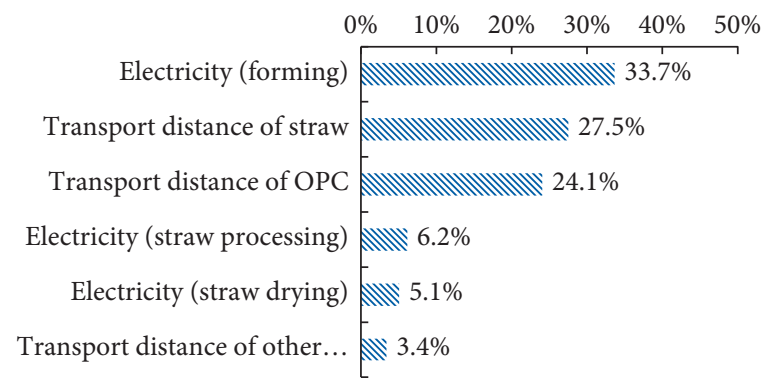

(b)

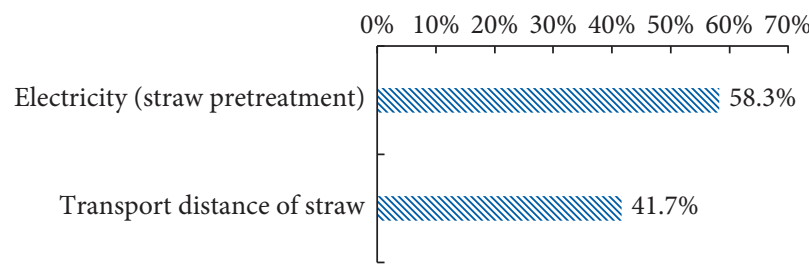

(c)

FIGURE 11: Sensitivity analysis of contribution to variance in greenhouse gas emissions of Scenario 1 (a), Scenario 2 (b), and Scenario 3 (c).

improve the utilization of raw stocks. The contribution rates of power consumption (including crushing, screening, shaping, and packaging) are $62.9 \%, 45 \%$, and $58.3 \%$ of the change in greenhouse gas emissions under three scenarios, respectively. Therefore, the emission reduction of the system depends on the development of energy-saving technologies in the energy conversion process (especially in the shaping process). In addition, controlling the transportation distance of other materials is also essential to ameliorate the overall environmental protection level of the system.

\section{Conclusions}

In this study, the inventory data of the four typical scenarios about recycling and disposal of straw resources were calculated by LCA. Comparable studies were conducted on the 
greenhouse gas emissions, acidification effects, and nonrenewable energy consumption of each scenario. Some specific conclusions are summarized as follows:

(a) Reusing straw on the fiberboard production or combustion power generation is a feasible pathway from the environmental and technical view. Production and transportation process of catalysts, $\mathrm{OPC}$, and the combustion power generation process have been the largest parts of impacting on the environment in Scenarios 1, 2, and 3, respectively. Enterprises are suggested to improve their technological approaches to reduce pollutant emissions following these aspects.

(b) From the perspective of environmental impact, the straw particleboard is the optimal scheme for recycling and reusing crop straw resources. The open-air burning of straw generates the highest pollutant emissions with the greatest impact on GWP and AP, which is the least desirable scheme. The government is supposed to emphasize on air pollution caused by the open burning of crop straw. It is important for the government to establish the comprehensive utilization industry chain, effective policy subsidies, and incentive policies.

(c) According to the results of the sensitivity analysis, the power consumption during the forming process and straw transportation distance are the main factors affecting the environmental performance in Scenarios 1 and 2. It is necessary to strengthen the energy-saving technology for molding and control the radius of straw transportation.

\section{Data Availability}

The test data are included within the article and can be made freely available.

\section{Conflicts of Interest}

The authors declare no conflicts of interest.

\section{Acknowledgments}

This research was supported by the National Natural Science Foundation of China (Grant no. 51708091) and the Jilin Science Foundation for Distinguished Young scholars (Grant no. 201831711).

\section{References}

[1] P. Wang, J. Wang, Q. Qin, and H. Wang, "Life cycle assessment of magnetized fly-ash compound fertilizer production: a case study in China," Renewable and Sustainable Energy Reviews, vol. 73, pp. 706-713, 2017.

[2] M. Wang, L. Zhao, Y. Tian et al., "Analysis and evaluation on energy utilization of main crop straw resources in China," Transactions of the Chinese Society of Agricultural Engineering, vol. 24, no. 12, pp. 291-296, 2008.
[3] R. Petkovaslipets and P. Zlateva, "Thermal insulating properties of straw-filled environmentally friendly building materials," Civil \& Environmental Engineering Reports, vol. 13, no. 1,2017

[4] D. Liu, B. Dong, W. Li et al., "Preparation and performance test of formaldehyde-free innocuous and nonflammable straw particleboard," Transactions of the Chinese Society of Agricultural Engineering, vol. 33, pp. 301-307, 2017.

[5] F. U. Bin, L. I. Xin-Gong, P. Ya-Ge et al., "The preparation and properties of inorganic wheat-straw particleboard," Journal of Functional Materials, vol. 46, pp. 1112-1116, 2015.

[6] Y. Sun, W. Cai, B. Chen, X. Guo, J. Hu, and Y. Jiao, "Economic analysis of fuel collection, storage, and transportation in straw power generation in China," Energy, vol. 132, pp. 194-203, 2017.

[7] Y. Wu, L. Li, R. Xu, K. Chen, Y. Hu, and X. Lin, "Risk assessment in straw-based power generation public-private partnership projects in China: a fuzzy synthetic evaluation analysis," Journal of Cleaner Production, vol. 161, 2017.

[8] D. J. Carvalho, J. P. S. Veiga, and W. A. Bizzo, "Analysis of energy consumption in three systems for collecting sugarcane straw for use in power generation," Energy, vol. 119, pp. 178-187, 2017.

[9] E. Cheng, X. Sun, and G. S. Karr, "Adhesive properties of modified soybean flour in wheat straw particleboard," Composites Part A Applied Science \& Manufacturing, vol. 35, no. 3, pp. 0-302, 2004.

[10] E. D. Sitz, D. S. Bajwa, D. C. Webster, E. M. Monono, D. P. Wiesenborn, and S. G. Bajwa, "Epoxidized sucrose soyate-a novel green resin for crop straw based low density fiberboards," Industrial Crops and Products, vol. 107, 2017.

[11] X. P. Ye, J. Julson, M. Kuo, A. Womac, and D. Myers, "Properties of medium density fiberboards made from renewable biomass," Bioresource Technology, vol. 98, no. 5, pp. 1077-1084, 2007.

[12] K. R. Camann, D. C. Jansen, C. B. Chadwell, and B. Z. Korman, "Design and performance of load bearing shear walls made from composite rice straw blocks," in Proceedings of the Structures Congress 2010, pp. 1405-1416, American Society of Civil Engineers, Orlando, FL, USA, May 2010.

[13] S. Memon, I. Wahid, M. Khan, M. Tanoli, and M. Bimaganbetova, "Environmentally friendly utilization of wheat straw ash in cement-based composites," Sustainability, vol. 10, no. 5, p. 1322, 2018.

[14] M. Nazerian and V. Sadeghiipanah, "Cement-bonded particleboard with a mixture of wheat straw and poplar wood," Journal of Forestry Research, vol. 24, no. 2, pp. 381-390, 2013.

[15] W. Lin and W. Song, "Power production from biomass in den-mark," Journal of Fuel Chemistry and Technology, vol. 33, no. 6, pp. 650-655, 2012.

[16] T. Suramaythangkoor and S. H. Gheewala, "Potential alternatives of heat and power technology application using rice straw in Thailand," Applied Energy, vol. 87, no. 1, pp. 128-133, 2017.

[17] C. M. Sastre, Y. G. Arechavala, and A. M. S. Montes, "Evaluation of the environmental sustainability of the use of straw for electricity production," in Proceeding of the International Conference on Renewable Energy Research and Applications (ICRERA) 2013, pp. 722-727, IEEE, Madrid, Spain, October 2013.

[18] International Organization for Standardization, ISO 14040. Environmental Management_Life Cycle Assessment_Principles and Framework, International Organization for Standardization, Geneva, Switzerland, 2006. 
[19] International Organization for Standardization, ISO 14044. Environmental Management-Life Cycle Assessment-Requirements and Guidelines, International Organization for Standardization, Geneva, Switzerland, 2006.

[20] J. Clavreul, D. Guyonnet, and T.H. Christensen, "Quantifying uncertainty in LCA-modelling of waste management systems," Waste Management, vol. 32, no. 12, pp. 2482-2495, 2012.

[21] C. Wang, L. Zhang, Y. Chang, and M. Pang, "Biomass directfired power generation system in China: an integrated energy, GHG emissions, and economic evaluation for salix," Energy Policy, vol. 84, pp. 155-165, 2015.

[22] J. Wang, R. Wang, Y. Zhu, and J. Li, "Life cycle assessment and environmental cost accounting of coal-fired power generation in China," Energy Policy, vol. 115, pp. 374-384, 2018.

[23] C. Perilhon, D. Alkadee, G. Descombes, and S. Lacour, "Life cycle assessment applied to electricity generation from renewable biomass," Energy Procedia, vol. 18, pp. 165-176, 2012.

[24] P. Nuss, K. H. Gardner, and J. R. Jambeck, "Comparative life cycle assessment (LCA) of construction and demolition (C\&D) derived biomass and U.S. northeast forest residuals gasification for electricity production," Environmental Science \& Technology, vol. 47, no. 7, pp. 3463-3471, 2013.

[25] H. Kouchaki-Penchah, M. Sharifi, H. Mousazadeh, H. ZareaHosseinabadi, and A. Nabavi-Pelesaraei, "Gate to gate life cycle assessment of flat pressed particleboard production in Republic of Iran," Journal of Cleaner Production, vol. 112, pp. 343-350, 2016.

[26] H. Kouchaki-Penchah, M. Sharifi, H. Mousazadeh, and H. Zarea-Hosseinabadi, "Life cycle assessment of mediumdensity fiberboard manufacturing process in Islamic Republic of Iran," Journal of Cleaner Production, vol. 112, pp. 351-358, 2016.

[27] C. M. Piekarski, A. C. de Francisco, L. M. da Luz, T. H. d. P. Alvarenga, and J. V. M. Bittencourt, "Environmental profile analysis of MDF panels production: study in a Brazilian technological condition," CERNE, vol. 20, no. 3, pp. 409-418, 2014.

[28] C. M. Piekarski, A. C. de Francisco, L. M. da Luz, J. L. Kovaleski, and D. A. L. Silva, "Life cycle assessment of medium-density fiberboard (MDF) manufacturing process in Brazil," Science of The Total Environment, vol. 575, pp. 103111, 2017.

[29] M. D. L. Luz, C. D. F. Antonio, C. M. Piekarski, and R. Salvador, "Integrating life cycle assessment in the product development process: a methodological approach," Journal of Cleaner Production, vol. 193, pp. 28-42, 2018.

[30] S. M. Shafie, H. H. Masjuki, and T. M. I. Mahlia, "Life cycle assessment of rice straw-based power generation in Malaysia," Energy, vol. 70, pp. 401-410, 2014.

[31] J. Li and J. Wang, "Integrated life cycle assessment of improving saline-sodic soil with flue gas desulfurization gypsum," Journal of Cleaner Production, vol. 202, pp. 332-341, 2018.

[32] T. Silalertruksa and S. H. Gheewala, "A comparative LCA of rice straw utilization for fuels and fertilizer in Thailand," Bioresource Technology, vol. 150, pp. 412-419, 2013.

[33] G. Juan, Ti. Chaopu, and C. Ning, "Environmental comparison of straw applications based on a life cycle assessment model and emergy evaluation," Bioresources, vol. 10, no. 1, pp. 548-565, 2014.

[34] S. Soam, P. Borjesson, P. K. Sharma, R. P. Gupta, D. K. Tuli, and R. Kumar, "Life cycle assessment of rice straw utilization practices in India," Bioresource Technology, vol. 228, pp. 8998, 2017.

[35] S. Soam, M. Kapoor, R. Kumar, R. P. Gupta, S. K. Puri, and S. S. V. Ramakumar, "Life cycle assessment and life cycle costing of conventional and modified dilute acid pretreatment for fuel ethanol production from rice straw in India," Journal of Cleaner Production, vol. 197, pp. 732-741, 2018.

[36] M. U. Hossain, S.-Y. Leu, and C. S. Poon, "Sustainability analysis of pelletized bio-fuel derived from recycled wood product wastes in Hong Kong," Journal of Cleaner Production, vol. 113, pp. 400-410, 2016.

[37] M. U. Hossain, Z. Wu, and C. S. Poon, "Comparative environmental evaluation of construction waste management through different waste sorting systems in Hong Kong," Waste Management, vol. 69, pp. 325-335, 2017.

[38] M. U. Hossain, C. S. Poon, I. M. C. Lo, and J. C. P. Cheng, "Comparative LCA on using waste materials in the cement industry: a Hong Kong case study," Resources, Conservation and Recycling, vol. 120, pp. 199-208, 2017.

[39] S. Raychaudhuri, "Introduction to monte carlo simulation," in in Proceedings of the 2008 Winter Simulation Conference, Global Gateway to Discovery (WSC) 2008, December 2008.

[40] B. Rivela, A. Hospido, T. Moreira, and G. Feijoo, "Life cycle inventory of particleboard: a case study in the wood sector $(8$ pp)," The International Journal of Life Cycle Assessment, vol. 11, no. 2, pp. 106-113, 2006.

[41] K. Ishii and T. Furuichi, "Influence of moisture content, particle size and forming temperature on productivity and quality of rice straw pellets," Waste Management, vol. 34, no. 12, pp. 2621-2626, 2014.

[42] CLCD, "Fuel combustion-diesel-CN-AP," in Chinese Life Cycle Database Version 0.8., Sichuan University, Chengdu, China, 2010.

[43] CLCD, "Cement production (dry method)-CN-AP," in Chinese Life Cycle Database Version 0.8, Sichuan University, Chengdu, China, 2010.

[44] CLCD, "Bulk cargo shipping (2500t)-CN-AP," in Chinese Life Cycle Database Version 0.8, Sichuan University, Chengdu, China, 2010.

[45] Ecoinvent, "Paraffin production (RoW)," in Ecoinvent System Processes, Swiss Centre for Life Cycle Inventories, Ecoinvent, Zürich, Switzerland, 2013.

[46] CLCD, "Electricity generation, China southern grid," in Chinese Life Cycle Database Version 0.8, Sichuan University, Chengdu, China, 2010.

[47] ISO, Cement-Bonded Particleboards Boards of Portland or Equivalent Cement Reinforced with Fibrous Wood Particles, p. 13, ISO, Geneva, Switzerland, 1987.

[48] CLCD, "Heavy-duty diesel truck transportation (30t)CN-AP," in Chinese Life Cycle Database Version 0.8, Sichuan University, Chengdu, China, 2010.

[49] Ecoinvent, "Calcium chloride production, solvay process (RoW)," in Ecoinvent System Processes, Swiss Centre for Life Cycle Inventories, Ecoinvent, Zürich, Switzerland, 2013.

[50] Ecoinvent, "Treatment of waste wood, untreated, sanitary landfill (waste treatment) $\mathrm{CH}$," in Ecoinvent System Processes, Swiss Centre for Life Cycle Inventories, Ecoinvent, Zürich, Switzerland, 2013.

[51] G. D. M. Dassanayake and A. Kumar, "Techno-economic assessment of triticale straw for power generation," Applied Energy, vol. 98, 2012.

[52] B. Zhao, H. Xu, T. Zhang, X. Nan, and F. Ma, "Effect of pyrolysis temperature on sulfur content, extractable fraction 
and release of sulfate in corn straw biochar," RSC Advances, vol. 8, no. 62, pp. 35611-35617, 2018.

[53] H. Zhao, X. Zhang, and M. Zhai, "Analysis on dynamic cost of straw direct combustion power generation," Journal of Chinese Society of Power Engineering, vol. 35, no. 5, pp. 412-417, 2015.

[54] Ecoinvent, "Heat production, at hard coal industrial furnace (RoW)," in Ecoinvent System Processes, Swiss Centre for Life Cycle Inventories, Ecoinvent, Zürich, Switzerland, 2013.

[55] X. Li, S. Wang, L. Duan et al., "Particulate and trace gas emissions from open burning of wheat straw and corn stover in China," Environmental Science \& Technology, vol. 41, no. 17, pp. 6052-6058, 2007.

[56] M. D. Hays, P. M. Fine, C. D. Geron, M. J. Kleeman, and B. K. Gullett, "Open burning of agricultural biomass: physical and chemical properties of particle-phase emissions," Atmospheric Environment, vol. 39, no. 36, pp. 6747-6764, 2005.

[57] Y. Zhang, M. Shao, Y. Lin et al., "Emission inventory of carbonaceous pollutants from biomass burning in the pearl river delta region, China," Atmospheric Environment, vol. 76, pp. 189-199, 2013.

[58] G. Cao, X. Zhang, Y. Wang, and F. Zheng, "Estimation of emissions from field burning of crop straw in China," Chinese Science Bulletin, vol. 53, no. 5, pp. 784-790, 2008.

[59] A. G. Eternit, Environmental Product Declaration (CementBonded Particle Boards), Institut Bauen und Umwelt e.V, Berlin, Germany, 2008.

[60] H. Liu, Y. Polenske, and J. e. Guo, "Comprehensive evaluation of effects of straw-based electricity generation: a Chinese case," Energy Policy, vol. 38, no. 10, pp. 6153-6160, 2010.

[61] X. Li, Z. Cai, J. E. Winandy, and A. H. Basta, "Selected properties of particleboard panels manufactured from rice straws of different geometries," Bioresource Technology, vol. 101, no. 12, pp. 4662-4666, 2010.

[62] Ecoinvent, "Heat production, hardwood chips from forest (RoW)," in Ecoinvent System Processes, Swiss Centre for Life Cycle Inventories, Ecoinvent, Zürich, Switzerland, 2013. 